\begin{tabular}{|c|c|c|}
\hline & $\begin{array}{l}\text { ANNALES INSTITUTI SLAVICI } \\
\text { UNIVERSITATIS DEBRECENIENSIS }\end{array}$ & \\
\hline SLAVICA XLVIII & 2019 & DEBRECEN \\
\hline
\end{tabular}

Татяна ИлиЕВА

\title{
АДВЕРБИАЛИЗАЦИЯ НА ПРЕДЛОЖНИ СЪЧЕТАНИЯ В СТАРОСЛАВЯНСКИ ЕЗИК НАРЕЧНИ И ПОЛУНАРЕЧНИ ИЗРАЗИ, ОБРАЗУВАНИ ПОСРЕДСТВОМ ПРЕДЛОГ ПО
}

\author{
Adverbialization and Prepositionalisation \\ of Prepositional Phrases in Old Slavonic \\ Adverbial and Semi-Adverbial Phrases with no Preposition
}

\begin{abstract}
The present paper is concerned with the adverbial and semi-adverbial phrases (with incomplete lexicalization), which are formed by prefixing a preposition to an autosemantic word in the Old Slavonic language. The empirical material is systematized on the basis of the prepositions involved in the word formation process, with regard to the adjuncts determined by the newly-formed adverbs and on the basis of the lexico-grammatical affiliation of the motivating word. The path of adverbialization is analyzed in each case and the systematic relations of the newly-formed adverbial units are also described.
\end{abstract}

Keywords: Old Slavonic language, lexical and syntactic word formation, adverbialization

Предлаганата статия е част от поредица публикации, в които на базата на ексцерпиран от основните палеославистични лексикографски трудове ${ }^{1}$ материал в диахронен аспект се разглежда лексико-синтактичното образуване на наречия чрез сливане в едно словесно цяло на устойчиви словосъчетания

1 В изследването насочено основно към историческия развой на наречието в българския език, се привличат освен лексиката от КСП (по данни на СС и СтбР) още и тази на:

- стб. паметници, съхранени в по-късни преписи (по данни на МДРЯ, СДРЯ, LLPsl, СЯС);

- $\quad$ някои среднобългарски паметници (по данни на МДРЯ и LLPsl);

- $\quad$ някои цсл. паметници (по данни на ЦслР)

- $\quad$ за сравнение свидетелства от РКБЕНО, днешните диалекти и съвременния български книжовен език.

Списъкът с примери от доказано стб. произведения, запазени по късни преписи, на места се допълва с такива от паметници със спорен в науката произход или дори от доказано принадлежащи към други редакции. Това изследователско решение е продиктувано от идеята, че в основата на книжовните наречия в Slavia orthodoxa през Средновековието лежи старобългарският език. Навсякъде обаче се указва източникът на всяка дума, което не позволява объркване.

Широката изворова база е умишлено търсена, тъй като извлеченият от текстове с различна жанрова и хронологична принадлежност материал позволява цялостна визия върху разглежданата категория лексикални единици с оглед на тяхната поява в разнообразни контексти, дава възможност да се обозрат парадигматичните им връзки, по-конкретно синонимията и антонимията като отношения в системата на изследвания словен регистър, да се уловят общоезиковите словообразувателни тенденции в синхрония и диахрония. 
или съчетания на самостойна и служебна дума - предлог [ИлиЕвА 2017, 2018]. Научният принос на разработката се състои в това, че в нея на базата на предходните изследвания по този въпрос ${ }^{2}$ за пръв път в исторически план с оглед развоя на българския език процесьт на адвербиализация е представен от гледище на неговите функционално-граматически механизми. Проследява се ходът на формиране на един от сегментите на стб. лексика - образуването на наречия на базата на други части на речта с евентуалния им последващ преход в категорията на служебните думи, определя се ролята на морфолого-синтактическия способ в продуцирането на adverbia и тяхното място в системата на частите на речта в аспекта на взаимоотношенията им с другите класове думи.

Изследването е структурирано на класификационен принцип, систематизирайки емпиричния материал според различни критерии - първо в обединения въ3 основа на участващия при словопроизводството предлог, в рамките на всяко отделно обединение - с оглед на обстоятелството, което означават новообразуваните наречия (за място, време, начин, количество, причина), и найсетне - на базата на лексико-граматичната принадлежност на мотивиращата дума (съществително, прилагателно, числително, наречие, предлог). Диференциацията се опира на групово-типологичен анализ на конкретния материал. За всеки адвербиален израз се посочва пълнозначният компонент в състава му с неговото значение ${ }^{3}$, семантиката на лексикализираното съчетание и илюстративен пример за контекстуална употреба от привлечените в изследването лексикографски справочници с указване източника на ексцерпция. Привеждат

2 В палеославистичната наука тази категория думи е била обект на изследване нееднократно. Преглед на словообразувателните средства и принципи за създаването на наречия в историята на славянските езици, между които и българския, предоставят различните исторически граматики [МикЛошич 1899, LESKIEN 1919, МилЕтич 1946, МЕйЕ 1951, ВАЙАН 1952, LUNT 1955, КУЗНЕЦОВ 1956, БУСЛАЕВ 1959, БОРКОВСКИЙ-КУЗНЕЦОВ 1963, МИРЧЕВ 1963 , AitZeTMÜLleR 1978, ДоБРев 1982, Илчев 1993а, б, СЛАВОВА 2017 и др.]. Поради неизбежните ограничения в обема на съответните ръководства обаче този активен, твърде сложен и многостранен процес не е обхванат от съставителите им в неговата действителна мащабност обстоятелство, което неминуемо е рефлектирало върху качеството на отразяване на феномена адвербиализация в трудовете по историческа лексикография на славянските езици. Остаряла е вече и публикуваната през 1910 година монография на Ал. Дорич за употребата на стб. наречие [DORITSH 1910]. В по-ново време от различни гледни точки тази категория думи е разглеждана в отделни публикации на редица слависти-медиевисти [ВЕлчЕВА 1964, ЯН 1967, MosZYŃSKi 1976, ЧурMAEBA 1980, ХАРАЛАМПиЕв 1980]. Специално място темата заема в работите на В.С. Ефимова (ЕфимовА 1989а, б, в; 1991а, б; 2006). В своята кандидатска дисертация изследователката съставя изчерпателен списък на пълнозначните наречия в стсл. език, анализира връзките им с другите части на речта и въз основа на тези данни определя начините на речепроизводство при тази категория думи, както и основните словообразувателни типове наречия, разглежда въпроси на тяхното функциониране в езика на стсл. ръкописи [ЕфимовА 1989б]. Въпреки систематичността и задълбочеността на изследването то обхваща материал от ограничен кръг паметници, принадлежащи към класическия стб. корпус - предимно сакрални текстове, еднородни по съдържание и жанрова характеристика, което неминуемо редуцира и фрагментира перспективата на филологическото изследване.

3 Целта на тази информация е разкриване на смисловите изменения, настьпващи в процеса на адвербиализация. 
се и гръцките съответствия на разглежданите лексикални единици (когато откъсът е от преводен текст). Във всеки конкретен случай се анализира пътят на адвербиализацията, проследяват се системните връзки на новообразуваната наречна единица. На отделни места се засягат антонимията и синонимията за по-пълно изясняване на семантиката. Наблюденията върху лексикализираните предложни изрази в исторически план се паралелизират с изследването на Ст. Георгиев върху наречната система в съвременния български книжовен език [ГЕОРГИЕВ 1976: 433-516].

На следващите страници ще спра вниманието си върху наречните и полунаречните (с незавьршена лексикализация) изрази, образувани чрез предлог по в стб. език.

Засвидетелстваните в средновековните писмени паметници наречия, продуцирани в резултат на предложно именно лексикализиране с участието на предлог по + пълнозначна дума, в стб. език са продуктивна и твърде многообразна група по отношение на принадлежащите към нея производни лексеми. По този начин са произведени адвербиални съчетания за място, време и качество.

\section{1. Наречия за място}

Мотивирани са от нарицателни имена за пространствени понятия (врьХъ,

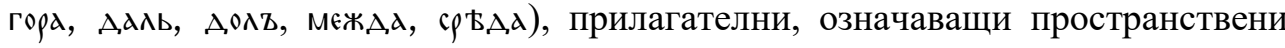
признаци (Алъгъ, Близъ), предлози (мєжА, и, ср'вА Z). В някои случаи са възможни различни пътища на възникване - направо от съответното име или индиректно през негова адвербиализирана, респ. препозиционализирана 4 падежна форма. Често пьти така получените адвербиални изрази стоят в разположение и единство до местоимение в д. п. или съществително име в р. п., означаващо ориентиращия предмет. Оттук и по-силната предложна функция на част от тези лексикализирани предложни сьчетания и по-слабо изразеното им адвербиално значение.

Тенденция към семантична цялостност по посока на лексикализиране се наблюдава при засвидетелстваното в LLPsl наречно съчетание поврьхъ 'отгоре', мотивирано директно от съществителното врьхъ ${ }_{1},-$ - 2 . 'врьх', или индиректно - от негова препозиционализирана форма (врьхъ+ р.п. 'отгоре на'), т.е. като срастване на два предлога. Същото се употребява в комбинация с име в р.п., което му придава притежателно значение (несвободна употреба в предложна функция): поврьхъ столd mon.-serb. При лексикализацията на израза се наблюдава промяна в семантиката на мотивиращото сьществително от конкретно към абстрактно значение на 'място, разположено по-високо спрямо ориентира'. Обликът е възникнал вторично чрез ськращаване на флексията за съответния косвен падеж поради нейната десемантизация. Нвб. срв. продуцираните на базата на повръ $x$ съществителни повърхност, повърхнина и техните производни.

4 Препозиционализация се нарича преминаването на друга част на речта, обикновено съществително или наречие, в класа на предлозите. 
Допълнителна вторична промяна на адвербиалното значение с обстоятелствен признак за място към качествено-определителна семантика с последваща десубстантивация на мотивиращото име и заличаване на деклинационната му морфология се наблюдава при лексикализираната предложно-именна синтагма на предлога по и съществителното гора, засвидетелствано в значението

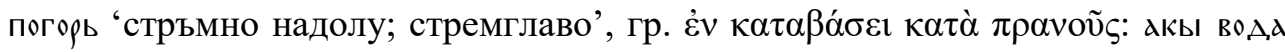
исход,Ащи погорь Мих1:4. На тази семантична промяна се дължи честата употреба на израза с допьлнително уточняващото го като локализация наречие за място низь, на свой ред определяно по отношение на начина на протичане на действието от погорь: низь погорь хлъмоу поущенъ men.-leop. 145; низь того погорь поущєноу и съшьдььшоу зд.рдвоу теn.-lеор. (в несвободна употреба заедно с име, респ. местоимение в р.п., придаващо му притежателен признак). Вж. също регистрираните в LLPsl с примери от сръбски паметници съчетания на погорь crys.-duš. 15.43. на oу погорь/ оу на погорь mon.-serb., които свидетелстват за напълно завършената лексикализация на погорь. Произв. погорьмъ.

Двойна, дори тройна мотивация може да се предположи при наречното съчетание по ддли 'на разстояние; далече' - от съществителното ддль, -и ж. 'далечина' съответно през негова падежна форма в адвербиална (дАли 'далече, на разстояние') или предложна употреба ( $\lambda$ дли $2+$ р.п. със значение 'далече от, на разстояние от'). Контекстуалното свързване с глаголи за статика и динамика модифицира неговата семантична структура в посока към два аспекта: за местонахождение на отстояние и за отделителност (гр. $\mu \alpha \kappa \rho o ́ \theta \varepsilon v): C_{\text {ВА, }}$ прямо емоу по, для Бт21:16 по ркп. от XIV в. Сташа под,дль Изх20:18 по ркп.

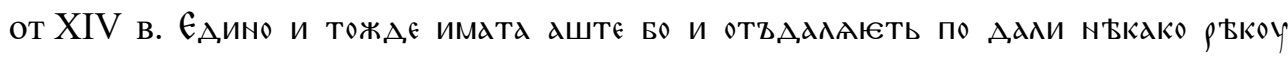

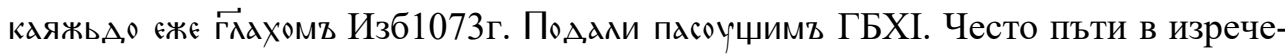
нието се отбелязва и ориентирьт (с предлог отъ): ПръжА,є Гдадною мьнимо юсть ОТВ ИСТОЧЬНИКА ОТВА, ВААТИ СА ПО АААИ НВ НАЧААО КВ МАТИЦИ КВ ИНОСТАНЬНОМОУ

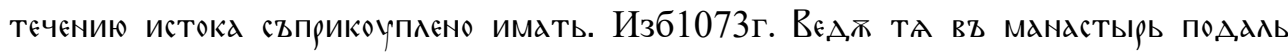
отъсюд, ПатСинХІв. поддлє отъ иєрочсдлимд КирТур. В подобни случаи трудно може да се каже наречието ли определя предложния израз или, обратното, предложният израз уточнява наречието. Така или иначе, на тази база се развива съставният предлог по А,дли отъ. Дублетните облици по,Адль и по,дАли, възхождащи към в.п. и м.П. на мотивиращата пълнозначна дума, се употребяват без значение дали означават посока (при глаголи за движение) или местоположение. По,дллє и по,длл в биха могли да се обяснят с формализиране на морфологичната структура по аналогия със съответните деадективни наречия на -є и

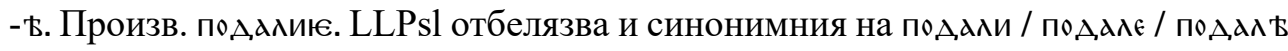




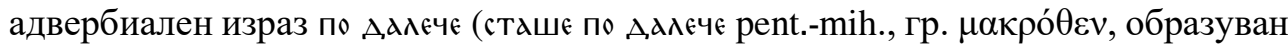
от сливането на предлога по с деадективното наречие Адגєчє.

След срастване на предлога по със сьществително *dьlja 'дължина' [ФАСМЕР 3, 297] се е появило лексикализираното съчетание подли / подьл в / по,Ає 'покрай'. Така образуваното наречие е неактуално като пълнозначна дума, превръщайки се в семантичен център на съчетание, разширено чрез съществително име в р.п. за притежание, назоваващо ориентиращия предмет, по отношение на който се означават координатите на локализацията, или, казано иначе, употребява се като несъщински предлог 'по протежение на'. Дублетните облици на думата предоставят чудесен пример за това как деграматикализацията на падежните окончания при синтактичната транспозиция довежда до преобразуването на някои от тях като словообразувателни форманти с чисто деривационна, но не и граматическа функция. Така възникват формите

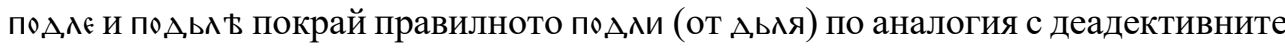
наречия на -ъ и -є. Това показва, че граматическата морфема, с която се образува съответната падежна форма на мотивиращата дума, не е активен морфологичен елемент на словоформата при наречния израз, неутрализира се семантически поради неизменяемост на формата и нейната аморфност. Настьпва декомпозиция, при която адвербиалните завършъци -є и -ъ се прибавят към основа, несъотносителна с прилагателно име.

Със заличена словообразувателна структура е близкозначното на горното наречие пол,ъАъ ‘близо, покрай’, възхождащо към изходна форма пололъ: Цри фоуникиини ижє под ВАъ мори ИсНав5:1 по ркп. от XIV в. Същото е мотивирано от съществителното долъ [ФАСМЕР III: 299]. Впрочем посоченото по горе на-

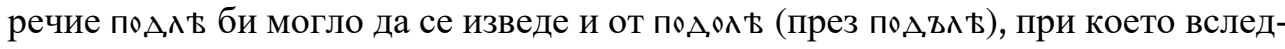
ствие на адвербиализацията първоначалната опозиция посока - местоположение се неутрализира.

Наречието пюздАи има абстрактно пространствено значение 'локализация на координатност по хоризонтала с ориентация към обратната, нелицевата страна на ориентационния обект'. Образувано е от съществителното здА, , -и ж. 'задница, гръб' (позд,и стхти Бт33:2) като резултат на лексикализация на предложно-именна синтагма. Възможен е обаче и друг път на развитие в резултат от сливане на две препозиции - по и здали в качеството му на вторичен предлог, получен на базата на морфолого-синтактично словообразуване от първообразното съществително. Нвб. диал. позад [БЕР 1: 585].

Идентично в структурно-семантично отношение с по здали е антонимното наречие по пръжю с абстрактно пространствено значение “локализация на коор- 
динатност по хоризонтала с ориентация към лицевата страна на ориентационния обект' (По прњжю храмх Изх26:9 в ркп. от XIV в.), базирано на съществителното пр'ъждь, -и ж. ‘предница, предна част’ .

Синоним на простите несъщински предлози мєжд.у, мєж(А)ь и мєж(А)и, възхождащи към вторично препозиционализирани форми от стб. мєжАд 'граница', е засвидетелстваният в паметниците адвербиализиран израз помєж(А)и, образуван от свързването на двата прости предлози по + мєж(А)и. Означава положение в пространството и времето, което разделя два предмета, респ. два момента; положение сред много предмети или части на сборен предмет, еднородна среда; прен. за отношения между хора. Документиран е в несвободна употреба заедно с дателно местоимение, респ. име в р.п., придаващо му притежателен признак: Помєжи рано и страшны пєци ХронГАм. Помєжи жє тьма женж

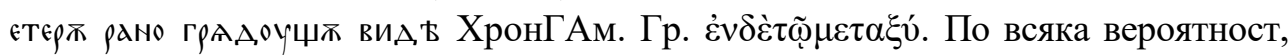
при все че не е засвидетелстван в палеославистичните лексикографски справочници, е съществувал и обликът помєжА.оу, ако се съди по наличието му в нвб. БЕР отбелязва и срещащите се в диалектите варианти помежд и помежда [БЕР 3: 715]. Произв. помежда диал. 'межда, граница, синор' [БЕР 3: 714].

Лексикализираната предложно-именна синтагма по с $\wedge$ ВА, оу се употребява предимно с глаголи за движение (ити, ходити, шьствовати и др.). Морфологичните варианти посл $\mathrm{B} \lambda \mathrm{n}$, посл $\mathrm{B} \Delta \mathrm{b}$, посл $\mathrm{B}, \mathrm{z}$ се използват винаги за означаване на темпорално отношение (вж. по-нататьк). Всички те възхождат към същест-

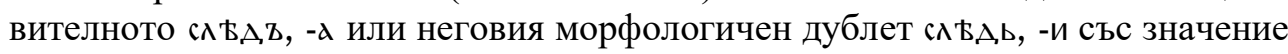
'следа, стьпка, която е останала подир придвижването на предмета': Шьствоую нынЊ по сл ВА, оу оучитєлю КПреслУЕ. Докато в приведения пример от стб. паметник конкретната семантика на пьлнозначната дума е все още жива, в понататьшния процес на лексикализация тя избледнява и в рамките на адвербиалното съчетание започва да означава най-общо локализация на координатност по хоризонтален ориентир 'отзад'. Предлогът по на свой ред свързва действието със значението за място или момент подир нещо, за действие или предмет подир друго извършване или предмет. Впоследствие допълнително се десемантизира и наречният израз, чието първоначално лексикално, самостойно значение се превръща в несамостойно, незнаково, елементарно означение на служебно съчетание със семантичен признак 'място на действие или движение в непосредствена близост или на известно неголямо разстояние откъм гърба на някого или откъм задната страна на нещо, което се движи': след, зад, т.е. придобива функция на несъщински предлог + име в р.п. с притежателно значение. По с $৯$ В, оу е по-рядък синоним на съответното съчетание на същест-

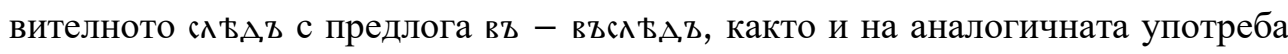
на простия предлог по (.....н можєши нын' по мьн' ити Йо13:36 Остр). 


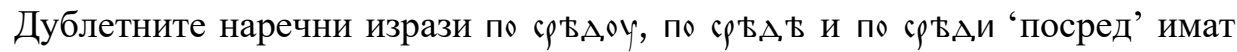
значение за ограничаване, локализиране спрямо дадена част от ориентиращия предмет, приемана в известен смисъл за негова среда. Същите стоят по-често в разположение и единство до съществително име в р.п., означаващо ориентиращия предмет. Оттук и по-силната предложна функция на тези наречия и послабо изразеното им адвербиално значение. Образувани са от срастване на предлога по със сьществителните ср'в, В, -д ж. 'среда', засвидетелствани в паметниците почти изключително в лексикали-

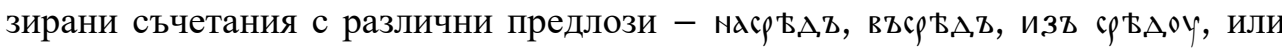

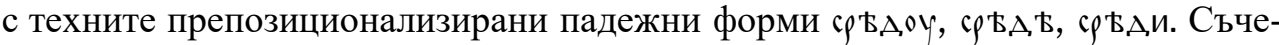
тават се с времеви и пространствени понятия:

По срьд, у - 1. Като нар. а) Посред. Оврьте съсоуды посрьд, оу ПатСинХІв. б) В промеждутька (за време) Врьма въ посрьдоу мънога ГрНис /МЧФевр/. 2. Като предл. Посред. Разоум'и яко поср'ва.оу сьтии стжпаєши Изб1073г. По срвдоу градад ЖитПорф /МЧФевр/.

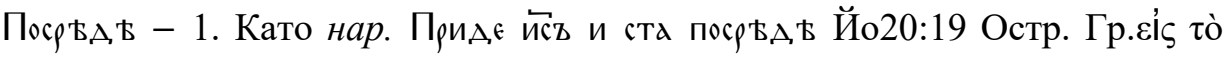
$\mu \varepsilon \dot{\sigma o v}$ 2. Като предл. Посред. Повєль єА,иномоу отъ Брдтиға съвьрдти въ кошь оукрочхы ты и несъшє, посрьда в рбкы въсыпати я НестЖитТеод.

ПосрБа,и - Като предл. Посред. ВрджА,оу положоу по ср'А,и теББ и по ср'А, жены

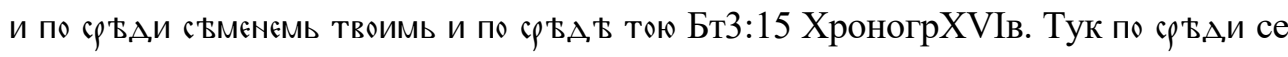
използва преносно за отношения между хора като синоним на помєжди с повтаряне на предлога при всяка от думите, именуващи съотнасящите се обекти.

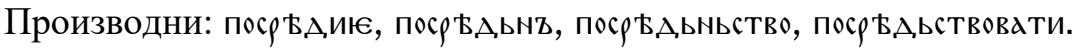

От прилагателни са мотивирани лексикализираните съчетания векторни антоними по десн' върху което се извършва действието без определена посока, за разлика от съответните изрази с други предлози (на, о): начд стдвити грады по д,єсн' ПВЛ.

От срастване на предлога по с прилагателно се е получил несъщинският предлог под,лъгъ, употребяван с р.п. за означаване на местонахождение 'по протежение на, покрай' (По,льгъ моря Бт49:13 по ркп. от ХІVв. Под,лъгъ р'вки

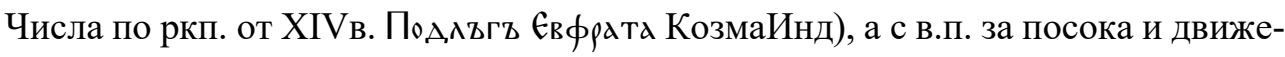

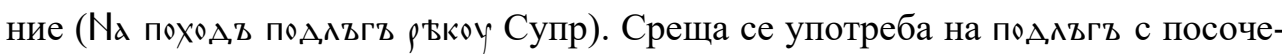
ните два падежа и без значение дали означава посока (при глаголи за движение) или местоположение. Срв. текстологичните варианти на един и същ контекст По, лъгъ пжть Бт38:14 по ркп. от XIVв. - в др. преп. по,Алвгъ пжти. Вж.

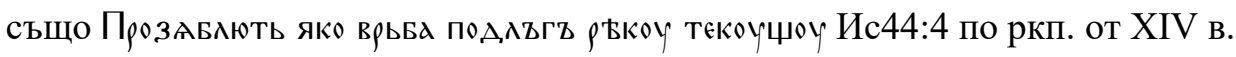


При наречния израз по простъ 'прямо, направо' (Поид,ємъ попростъ Бт33:12

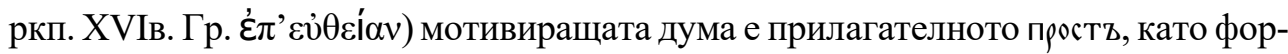
мата за м.р. би могла да се обясни с изпуснато мъжкородово име - пжть 'път'. Наблюдава се допълнителна вторична промяна на адвербиалното значение с обстоятелствен признак към качествено-определителна семантика. LLPsl отбелязва също и близкозначните на по простъ наречни изрази по прькоу и попр'ъкъ, съотнасящи се помежду си като граматически дублети, при които опозицията местонахождение - движение с адвербиализацията се неутрализира.

Пълнозначната дума в лексикализирания израз по странь със значение 'по наклон'(ГригПапа) е наречието странь ‘против, срещу', образувано вследствие на десубстантивация на сьществителното ,страна'.

При сливане на предлога по с показателното наречие за място тдмо е образувано адвербиалното съчетание по тамо: Nє можєши волєє по тамо отъ сєго м Вста поити Прол.

Производно от срастването на предлога по с обобщителното местоименно

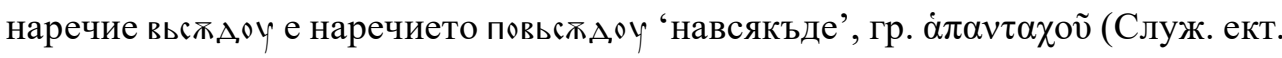
суг.). До голяма степен предлогът по в този случай служи като допълнителен експликатор на имплицитно съдържащата се в изходния адвербиум семантика, свързана с представата за сборност, всеобхватност и интензивност на извършваните действия или повторителност на едно действие на много места и от много субекти.

МДрРЯ отбелязва с илюстрация от късен руски паметник (грамота) продуцирания в резултат от сливане на предлога по с выпросителното местоименно наречие за място кжа.оу адвербиум покоуд.оу (стб. покжд.оу), употребен в приведения пример преносно в темпорално значение 'докато'. Ракурсивният момент в семантиката на посоченото наречие, неговата дейктичност, както и основният му признак на дума с обстоятелствено и определително адвербиално значение го транспортират в сферата на подчинителните съюзи, въвеждащи зависими изречения за място и време. Необходимо условие за употребата на анализираната дума като конюнкция е позиционирането ѝ между две синтактични единици и превръщането ѝ в показател за смислово-синтактичните отношения между тях. Локализацията като семантизация на наречието за място може да се възприема като значение на време по силата на определени синтактични условия, обобщаващи я като случай на времева дистрибуция на действието. Такова синтактично условие предоставя употребата на местоименното наречие за място като съюзна дума в подчинено изречение, което има всички други лексикални и вътрешно-синтактични условия да се възприеме като изречение за време. 


\section{2. Наречия за време}

В лексикализирани съчетания, мотивирани от нарицателни имена за темпорални понятия, а също и от прилагателни, имащи в семантичната си структура признаци, близки до признаците за време или сходни по своята семантика до представата за някаква хронология и количествена измеримост (ранъ, мдлz, мъногъ), предлогът по може да означава времето, в което се извършва действието, продължителност на време или че действието се извършва по-късно от даден момент или след друго действие.

Лексикализираната предложно-именна синтагма по вр'вмєни ,навреме' се синонимизира със съответното съчетание на предлога въ. Адсть АъжАь зємли по времени раныи и поздьныы Втз11:14 по ркп. от XIVв. Гр. каӨ’ врБМА врачьство Пакость воуд,єть ПНЧ. [ИЛИЕВА 2017: 84-107]. В тези случаи вследствие на процеса на адвербиализация изходните предложно-именни синтагми губят в известна степен изконното обстоятелствено значение за определено темпорално отношение и придобиват по-абстрактна и обобщена семантика на вътрешно присьщо на действието качество.

От гоА Z - другото основно наименование на 'време' в стсл. - е мотивирано лексикализираното наречно съчетание погодь 'съответно; по необходимост',

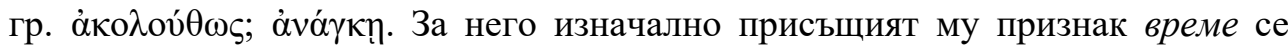
оказва вече несьществен. Той се е запазил само като вътрешна форма, като начален признак за формиране на неговото значение, което в процеса на адвербиализацията се трансформира в качествена семантика, по своеобразен начин синтезирайки обстановка и квалитативна определеност. Произв. погодь 'нужда' и погодиє 'благоприятно време' (= погодд в древноруски паметници).

Лексикализираните изрази на предлога по с някои прилагателни могат да се обяснят като резултат от съкращаване на словосъчетание на прилагателно със съществителни като врьмА, чдсъ и под.:

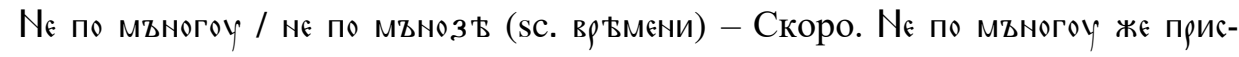

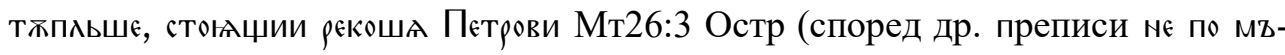

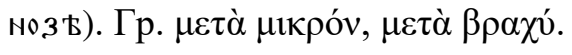

По мал в (sс. часъ) - След малко (време), наскоро. Почто в В просльзити, єгожє

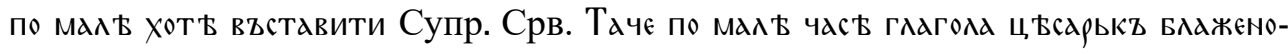

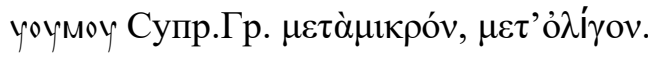

От примерите се вижда, че съответният наречен израз може да отнася действието и към миналото, и към бъдещето, означавайки непосредствено предхождащия или следващ момент.

Срв. също в древноруски паметници и цсл. текстове: 
По раноу (sc. вр Бмени)/по рано - Рано. Здоутра по раноу Псков1Л. Въ великыи

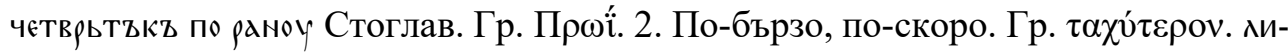
точргид вываєть ТП. Л. 194. съврьшаєть са саоужьва скоро и порано typ. chil. Производни: поранию, поранитиса.

Преносно за изразяване на времеви отношения при последователни дейст-

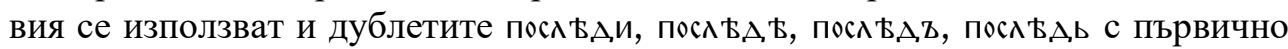
пространствено значение (вж. по-горе): Яможє азъ ид, , нє можєши нын' по мьн В

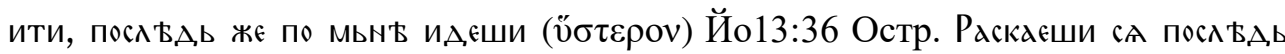

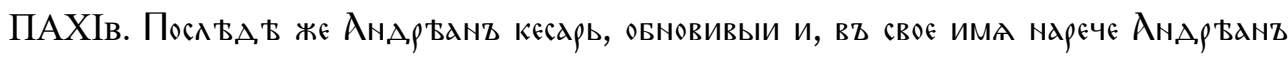
(за името на Адрианопол) ПВЛ. МєдВ жє каПАєть отъ оустенъ жєны АюБод, Виц, ...послВАВ жє оуво горьчБю злъчи оБрАщєши ПАХІв. Преобразуването на посочените предложни съчетания в наречия е станало със засилване и окончателно възприемане, затвърждаване на по-абстрактния признак на следходност, след като мотивиращите ги дублетни съществителни са загубили своето субстанциално значение (вж. по-горе при по сльА, У $)^{5}$.

Тук е мястото да отбележа и наречието посльждє, образувано от адвербиализирана форма за срв. степен ${ }^{6}$ на адективната употреба на посль $\mathrm{b}, \mathrm{b}$ като несклоняемо прилагателно (със стара і̌- основа) ${ }^{7}$.

И до днес често се среща наречието посль 'в последствие, след това', нвб. после, чийто първообраз трябва да се търси в съчетанието по с $\mathrm{B} \mathrm{B}, \mathrm{Z}, \mathrm{c}$ промяна на конкретната семантика на съществителното с $\wedge$ В $\Delta \mathrm{z}$ 'диря' най-напред в пообобщено обстоятелствено значение за място, а след това чрез пренос и за време (сетнина). Обликът посль може да се обясни с редукция на втория, субстантивния компонент вследствие изпадане (апокопа) на денталния звук. Апокопата е чисто морфологична, защото фонетични предпоставки за това

5 Значителен е броят на мотивираните от основа посльд- думи в средновековните писмени па-

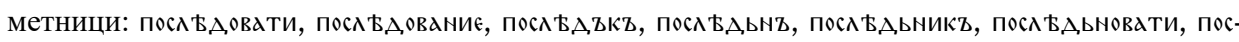

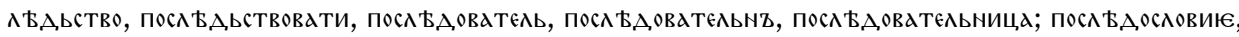
посльд,съв Бтиє. Вж. и в съвр. български диалекти последник, последно дете на многодетни родители“ (Разложко) [БEP V: 541]. LLPsl отбелязва и производните от синонима на посльд,

6 Формата за степен е семантизирана с признака за обособяване на наречието като отделна лексема.

7 Този широк функционален обсег на изходната дума, която, както виждаме, може да бъде съществително, прилагателно, наречие и предлог, свидетелства за нейната древност. Срв. употребата на послед в българските диалекти като съществително със значение ,плацента [БЕР V, 541]. Стсл. език е наследил от предисторическата епоха известен брой старинни по тип думи, които в процеса на развоя на езика, успоредно с диференциацията на частите на речта, са поели повече от една функции. 
липсват. В семантиката на наречието посль за разлика от изходното съчетание важна е хронологията, а не непосредствената близост на моментите и процесите.

Отделна група в категорията наречия за време формират лексикализираните предложно-наречни съчетания на предлог по с показателно местоимение (по томь / по сємь / по сихъ 'после, след това'), в които препозицията означава последователност в хронологията, поставяйки в една верига на протичане идващи едно след друго действия: Приимъ лєнтии, пр'поясд сА, по томь вълия вод, въ оумывальниц, и начАТЬ оумывати ногЫ оученикомъ Йо13;4 Остр. Си рєчє и

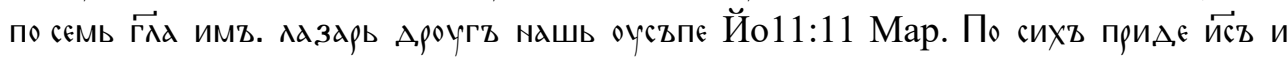

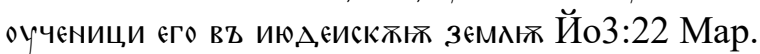

Другото темпорално значение на предлога по - продължителност на време: в течение на, в продължение на - се реализира в съчетанието му с относителното местоименно наречие вънєг $\lambda$ ג. И повънєгд,, , гр. ӧ $\varepsilon$, както и изходният адвербиум по силата на своята рекурсивност като заместителни думи изпълняват съюзна функция в изречението. Препозицията по в производното предложно съчетание само експлицира определен признак от съдържанието на мотивиращата, без да внася допълнителен нюанс в значението ѝ. Присъединяването ѝ не променя съществено семантиката на изходното съчетание вън-єгд, , следователно плеонастичното натрупване на още един предлог към базата (єгА, д) в случая има само обновяваща роля - да възстанови избледнялото значение на предлога въ.

Производно от съчетанието на предлога по с обобщителното местоименно наречие вьсєгдд е наречието повьсєгда. Предлогът по тук служи като допълнителен експликатор на имплицитно съдържащата се в изходния адвербиум семантика на всеобхватност и повторителност по отношение на много предмети и времеви моменти: Проскоуры повьсегд, да Бывдють Уст. пр. 1193 г.

Предлогът по присъства и в състава на синонимния на повьсегд, наречен израз повъинж, дублет навъинж 'винаги, всякога, постоянно'- за безкрайно протичащо или повтарящо се действие ${ }^{8}$. Засвидетелстван е в LLPsl с пример от Александрията.

Местоименните наречия за време понєли, понєлижє, понєл В, понєл БЖєє ,откакто' с предлог по в състава си означават граничен времеви момент, от който насетне

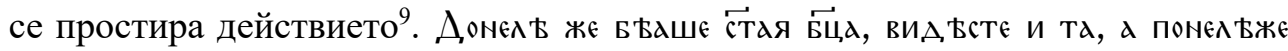

8 Наречието въинж е мотивирано от местоименното прилагателно инъ през междинна субстантивация на неговата падежна форма за ж.р.ед.ч. Препозицията въ в състава му престава да се усеща като отделен словообразувателен елемент със собствено значение, което довежда до плеонастично прибавяне на още един предлог с обновителна функция.

9 ЦслР отбелязва в сьщото значение и понєлико в Изх.9:24 (Острожка библия). 
отъидє, и вол В того не вид, всте ЖитАндрЮр. Nє высть сицє во египт'В, понели и выша чд, при тези наречия се извършва чрез посредството им в ролята на заместителни думи, които отпращат смислово към вече казаното, въз основа на което същите развиват свързваща синтактична функция, преминавайки в класа на съюзите.

\section{3. Наречия за качество и начин}

Мотивиращи при тази категория лексикализирани предложно-именни синтагми са предимно наименования на отвлечени понятия като воля, истинд,

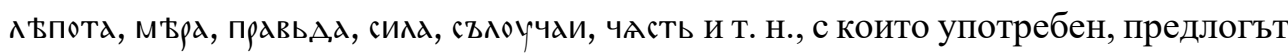
по има лимитативна семантика (характеристика откъм различни качества или област на действие), означавайки отношение на съответствие, начина на действието или основанието, съобразно с което става нещо. Такива са:

По вохи - Доброволно. Въ тьмьницж ид,ємъ по вохи Супр.

По истин' - Наистина, действително. По истин' вєликд чоудєсл вид, ВХомъ Супр. Синонимизира се със съответното наречно съчетание с предлог въ.

По льпоть - Подобаващо. По льпоть та въсхвдлити СинСлуж.

По мърь - Съобразно. Адасть Б̈ггодать по мърь СинЕвх.

По под, овью - По същия начин. Вьсемъ по под,овию разв В грьха Ен.

По правьд, в - Справедливо. Сжаи ми ги по правьд в твоєи Пс34:24 Син. Синонимизира се със съответното наречно съчетание с предлог въ.

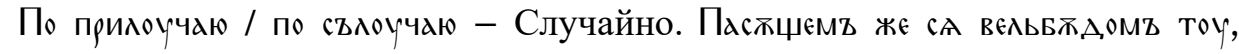

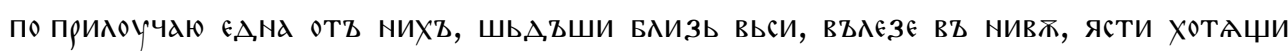
Супр. Оусврьте са по слоучаю съ львомъ ПатСинХІв.

По рал,оу - 1. Поред, последователно. По рад.оу писати Лк1:3 Остр.

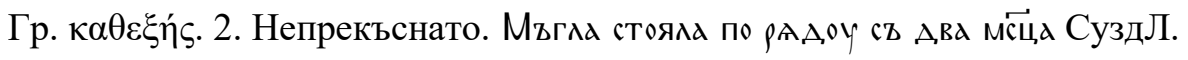

По сил в - Съобразно възможностите. Праздьновдти по силь РязКрм.

По таи - Тайно, потайно. Потаи посыхати Новг1Л.

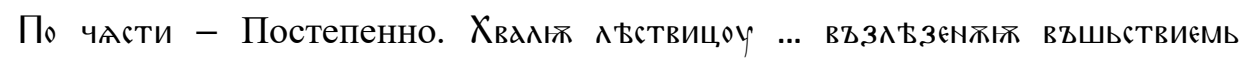
ПО чАСТИ на А,ОБРЪ нРАВЪ ГБХІв.

По рядко мотивиращо може да бъде съществително с конкретна семантика:

По плъти - По кръвно родство. По плъти жжика Гньь Остр.

По срьдьцоу - По сьрце, присьрце. Оврьтохъ мжжа по срьдцоу моємоу Супр разширено с определящо го лично притежателно местоимение, придаващо му посесивен признак. 
Мотивиращи при наречните изрази за качество с предлог по могат да бъдат и минали през етапа на субстантивацията качествени прилагателни, обикновено с по-абстрактно значение за състояние на предмета или лицето:

Аровьнв, -ыи прил. Дребен. ОТъ А.ровьнаго камения КирЙерусХІв. // По д.ровьноу - 1. На части. По д,ровьноу съзилдається градав ЕфрСирХІІІв. 2. Под-

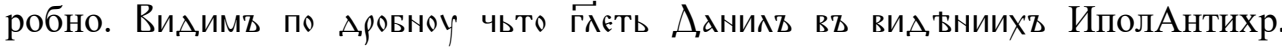

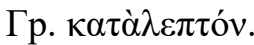

Истовъ, -ыи прил. Истински, действителен; сьщият // По истовоумоу Точно.По истовоуоумоу наоучитиса ИполАнтихр. ВрБма по истовоуоумоу поло-

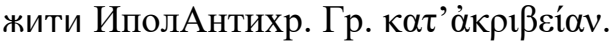

Косыи прил.Кос, наклонен. // Покось благоприятно. Потр'ьььн'ь и покось имъ пдд,ошА врджєния Ез21:23 (Упир). Плеонастично натрупване на предлози има в нд покось, идентично по значение с покось ‘благоприятно': В Втроу не на покось

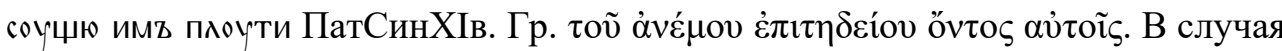
добавъчният предлог нд обновява избледнялото значение на препозицията по в мотивиращия наречен израз.

Кривъ, -ыи прил. Крив // По кривоу - Неправо; несправедливо: Прол. март 12. Гр. $\sigma \kappa о \lambda i \tilde{\omega} \varsigma$.

Аьгъкъ, -ыи прил.Който не тежи, лек // По льгъкоу - Леко, полека: Тп. л. 2.

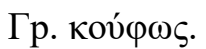

ОБихъ, -ыи прил.Обилен, щедър. Овило Адрованиє приимєтє Супр // По овилоу - Обилно. С кроустальными великыими оустрои, имоущи верхоу по овилоу задтоу СказБорГл.

Разьнъ, -ыи прил.Различен. // По разноу - Различно, разделно, на разни

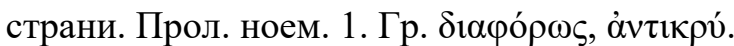

Рвавкъ, -ыи прил. Рядък. // По р'алкоу - Рядко Крм. л. 628. Гр. блаví

РБд, творИть мИлостыню, Паче творАџаго ПорВады Сб1076Г.

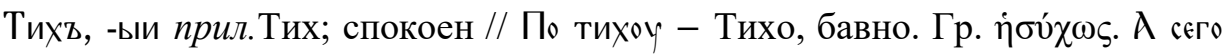
поути в ворз' не льзВ ходити, но по тихоу Дан. иг. Срв. Нвб. диал. потихом [БЕР 8: 61].

Тьнъкъ, -ыи прил.Тънък // По тънъкоу - Изтънко, в подробности, основно, изчерпателно. Под,бБАєТЬ всА По тънъкоу Пов ВА,Ати ПАХІв.

Интерес представляват адвербиализираните съчетания на предлог по с наречие в сравнителна степен:

入оучьшии прил. срв. ст. По-хубав. // По лоучше - По-хубаво. 
Кижь, -ии прил. срв. ст. По-ниськ. По нижь - По-ниско.

Производните наречия се противопоставят на мотивиращите ги с добавъчен семантичен признак за увеличеност, за по-голяма мащабност на признака на действието ${ }^{10}$.

Производно от съчетанието на предлога по с възвратното местоимение е наречието посовь 'отделно, на разни места': БышА жє и троуси страшьнии посоьь ХронГАм ркп. XVI в.

Съчетание на предлога по с числително име представлява наречният израз за качество и начин по єАлномоу 'едно по едно, подробно' (По, ,оБдєть по є⿻,иному о нємь повБдати ИполАнтихр), където предлогът реализира от многообразната си семантична прадигма значенията 'разпределение, последователност, постепенност'.

От сливане с друго наречие за начин се е получил адвербиалният израз по вьсьчьскы 'всякак, всячески': Ади жє имъ по вьсьчьскы творити правьд, т твоғ ЖитСтефПерм. Предлогът по в този случай служи като допълнителен експликатор на имплицитно съдържащата се в изходния адвербиум вьсьчьскы семантика на всеобхватност и многообразие по отношение на различните начини на действие.

С качествена семантика са и мотивираните от местоимения лексикализирани предложни синтагми, представящи обобщено значението за характерност:

-с показателно местоимение:

По семоу - Така. Горе егда рекжТТ д,оврБ о васъ вьси чёци, по семоу во творБаХ⿸丆 лъжиимъ пююкомъ оци ихъ Лк6:26 Мар.

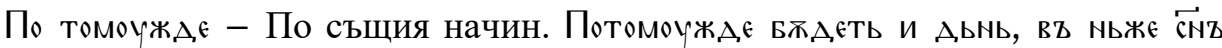
чҺ̈чьскыи Ввить сА Лк17:30 Мар.

-с обобщително местоимение за означаване всеобхватност, сгъстеност, пльтност с оглед начините на извършване на действието:

По вьсемоу - Подробно. По вьсємоу съказд ємоу, явивъши ємоу лжкавьныихъ

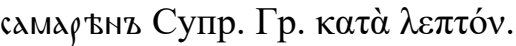

По вьсякомоу - По всякакъв начин. По всякомоу под,овити са мыслить дьстьць С

\section{4. Наречия за количество}

Предлогьт по в тези наречни изрази се употребява за означаване на слаба степен или на количеството, което се получава при разпределение, и се съчетава с мотивираща дума прилагателно име за количествен признак (малко :

10 Последващата партикулация, т.е. преминаването на предлога по в категорията на частиците, ще бъде разгледана на друго място. 
много). При адвербиализацията се получават антонимизиращи се помежду си съчетания:

Малъ, -ыи прил. // По мдлоу /по маль / по мдло. Малко, по малко, постепенно,

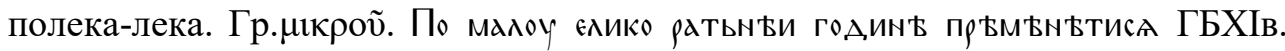

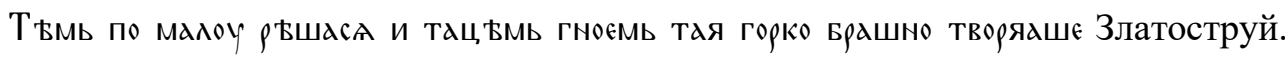

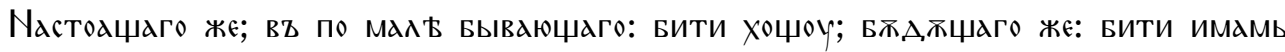
ЙоЕГрам. Єжє писахомъ прєжАє помдло СбХVІв. Срещат се и примери с повтаряне на прилагателното или на целия предложен израз, засилващо представата за постепенност: помдлоу малоу Втз7:22; помдлоу помдлоу Изх 23:30. Гр. кат'

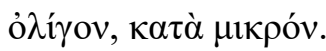

Вєлии прил. // По вєлию - Твърде. По вєлию оврадовавъ са ЖитТеодСтуд.

Вєликъ, -ыи прил. // По вєликоу - Твърде. ЄГожє люБлАшє По вєликоу ПВЛ.

Скоудв, -ыи прил. Недостатъчен. // По скоудоу - Немного. Азъ во єдинъ СБЖА, СЬА,

Мъногъ, -ыи прил. Многоброен. // По мъногоу - Доста. Вко по мъногоу исплънихомъ са оуничьжєния Пс122:3 Син. Гр. غ̇лі̀ $\pi$ одv́.

Првмъногъ, -ыи прил. Многоброен. // По прБмъногоу - Твърде много. Оугоди

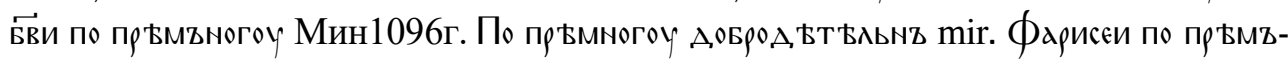
ногоу гръд в chrys.-lab. По пр'ммъногоу з Вло - Извънредно много Юдит 10:7.

Прьлихъ, -ыи прил. Преизобилстващ. // По прьлихоу - Извънмерно Ефес3: 20

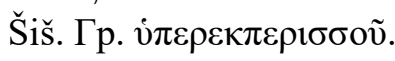

Пръизмиха нар. Чрезмерно. // По пртизлиха - Извънмерно LLPsl. Гр.

Тук можем да отнесем и предложно-субстантивното сьчетание по оумножєнию със значение 'нееднократно', засвидетелствано в ЕфрКрм (СТ̈ыи правьд,ьныи

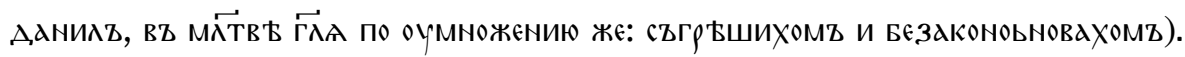

Местоименното наречие за количество със съюзна функция поюликоу 'доколкото; според колкото’ (по єликоу мощьно mon.serb.), образувано на базата на относителното местоимение єликъ 'колкото голям' с предлог по в състава си, благодарение на компонента дейктичност в значението си осъществява връзката с предходното изречение, като същевременно пази адвербиалната си употреба в състава на второто изречение.

\section{5. Наречия за причина}

Наречия за означаване на причина с предлога по се развиват на базата на пространственото значение за разположение и движение след нещо (което в някои случаи може да разкрива целта на движението). Образувани са от съчетание на предлога по с местоимение за предмет в състава си: показателно - 
потомоу 'по тази причина', въпросително - почьто 'поради каква причина', и относителни - понє и понєжє 'поради което', чиято абстрахираност и обобщеност предпоставя употребата им като съюзно средство със съседното изречение, изразяващо синтактична подчиненост. Ракурсивният момент в семантиката на посочените съчетания, тяхната дейктичност ги транспортират в сферата на текстуиращите елементи в речта, осъществяващи връзката между отделните синтактични единици (изречения и микротекстове). Наречията за означаване на причина с предлога по се синонимизират със съответните съчетания на препозицията за: Почьто мы и фарисьи постимъ сА мВного, а оученици твои ne постать са Мт9:14 Map.

6. Своеобразно отстьпително значение има наречието понъ 'най-малкото,

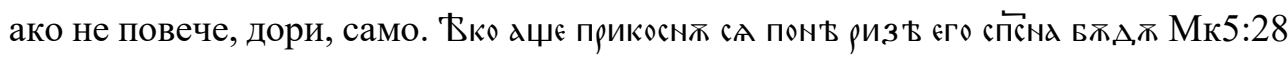
Мар. Покажи намъ пон' єдьно знамєниє Супр. С отрицание в изразите нє коли

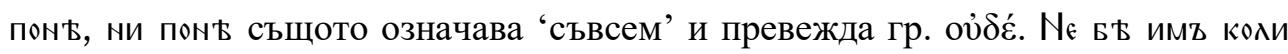
пон' всти Мк6:31 Мар. Къ томоу ти оуво ни пон' вьзьр'тти такомоу вывъшоу можєтъ Супр. Унаследено е от праслав. ponњ. Етимологически се извежда от по, което се родее с предлога по, и съкратена отрицателна форма от спомагателния глагол в 3 л. ед. ч. сег. вр. н' [БЕР 5: 515]. Нвб. поне.

В заключение можем да обобщим, че анализираната група лексикализирани предложно-именни синтагми, образувани с предлог по, са твърде многообразни по отношение на принадлежащите им производни. Те обединяват наречия за място, време, качество и количество, с мотивираща основа име (съществително, прилагателно), местоимение, предлог или друго наречие. Значителен е броят на производните с двояка, даже трояка мотивировка, чиято деривация може да се изведе еднакво логично както директно от изходното съществително, така и индиректно от негова наречна или препозиционална форма.

В процеса на адвербиализацията значението на предлога се придава на производните наречни изрази като семантична съставяща и той губи относителната си самостойност на служебна дума, за да се превърне в морфема. При това своеобразно „погльщане“ на предлога от семантиката на мотивиращата дума, той запазва известно конкретизиращо значение на ограничение.

Функцията на предлога в редица случаи може да се определи като обнови-

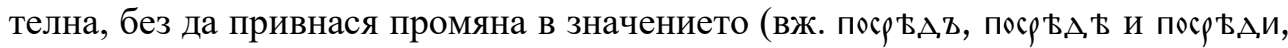

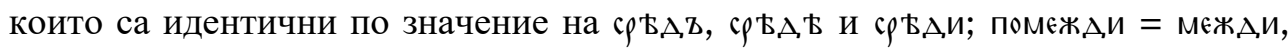

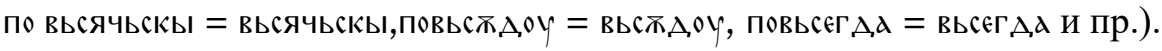

В състава на съчетанието пьлнозначната дума понякога променя семантиката си от по-конкретна към по-обобщено абстрактна (вж. по слЊВ, оч, по,Али, ПО врВМене, ПОГОАЬЬ). 
В рамките на анализираната група наречни и полунаречни синтагми синонимията и дублетността са широко застьпени. Синонимизират се:

а) адвербиални изрази с предлог по и морфологични дублети на една и съща

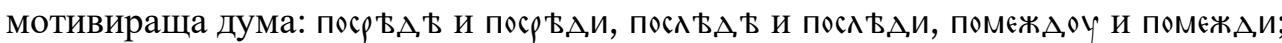

б) адвербиални изрази с предлог по и различни форми на една пълнозначна

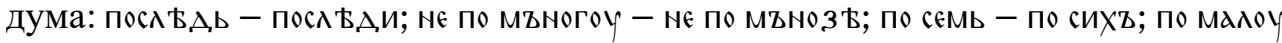
- По Маль - по мало;

в) адвербиални изрази с предлог по и различни мотивиращи думи: по прило-

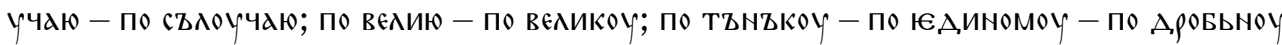
- По вьсемоY;

г) адвербиални изрази с една и съща мотивираща дума и различни пред-

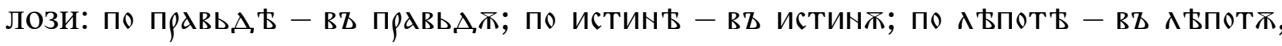

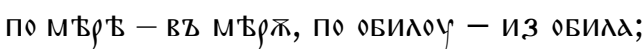

д) адвербиален израз с предлог по и мотивираща дума прилагателно срещу деадективно наречие: по тихоу - тихо; по овилоу - овило.

Резките семантични трансформации, семантичните скокове от един категориален вид наречие в друг, на които са подложени адвербиализираните предложни сьчетания, водят до развитие на полисемия, а понякога и до омонимия. Такива са категориалните преходи от наречие за място в наречие за време (посл $\mathrm{B} \triangle \mathrm{Z}$ ), от наречие за време в наречие за качество и начин (по врьмени) и др. В други случаи полисемията се развива в рамките на една и съща адвербиална категория на базата на експликация на различни нейни признаци (вж. по дровьноч, по рАд.оу).

Абстрактното значение на наречията от анализираната група, изразяващо поначало отношение, тяхната дейктичност, резултат от обобщеност на субстанциалност или квалитативност, нерядко ги поставя в по-особени дистрибутивни връзки с другите думи в изречението и ги подлага на допълнителни семантични и категориални промени, включително до преминаване към сферата на служебните думи - предлози и сьюзи. Така адвербиализацията, препозиционализацията и конюнкционализацията като тясно взаимосвързани транспозиционни процеси при едни и сьщи изходни думи се наблюдават активно не само в предписмения период на праслав. език, но и в историческия етап на писмената кодификация на стб. език, водейки на свой ред до интензивно развитие на лексикална полисемия и омонимия. 
На базата на адвербализираните предложни изрази се продуцират нови думи: прилагателни и производните им наречия (погодьнъ, под,роБьнъ, пол-

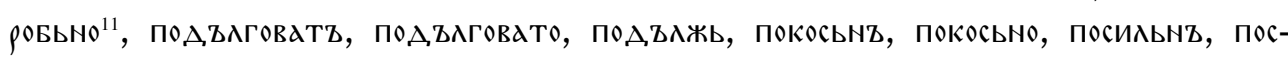

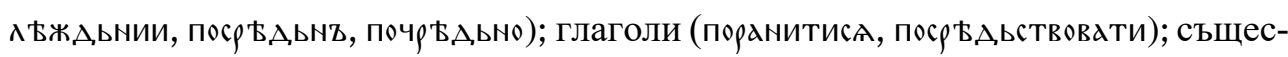

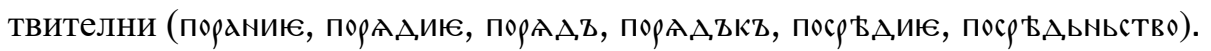

В преводни текстове адвербиалните изрази от разглежданата група в преобладаващата част от случаите превеждат грьцки наречия: $\mu \alpha \kappa \rho o ́ \theta \varepsilon v-$ по А,גли,

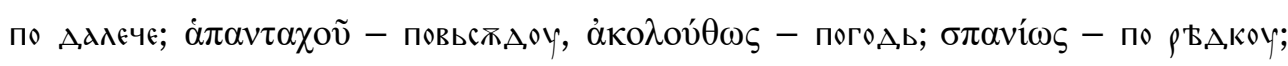

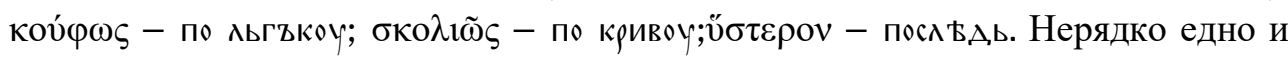
също преводно съответствие може да предава различни думи в езика на ориги-

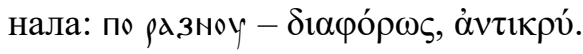

Друга част предават наречни съчетания с различни предлози в езика

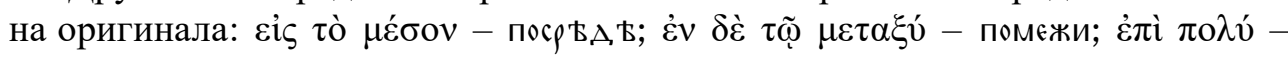
по мъногоу; До известна степен семантично припокриване се наблюдава между предлога по и гр. му еквивалент кат̀̀ в случаите, когато семантичното съдържание на съответните наречни изрази се изгражда върху признака за стесненост към

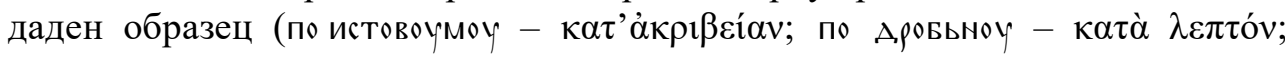

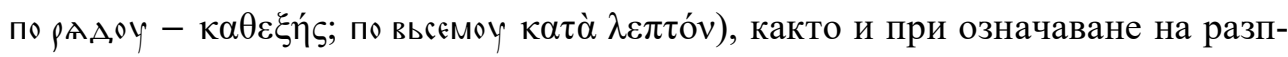

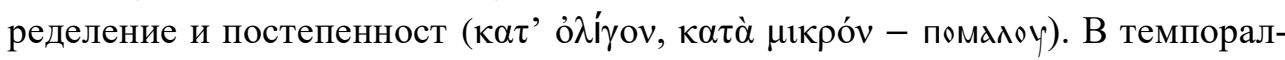
ната си употреба за означаване последователност предлогът по в наречни из-

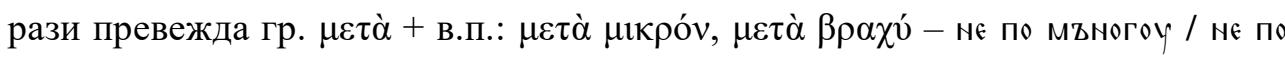

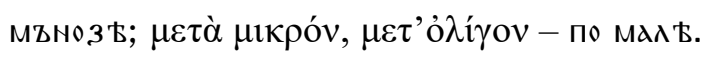

Примерите за свободни преводи също не са изключение: В втроу нє на покось

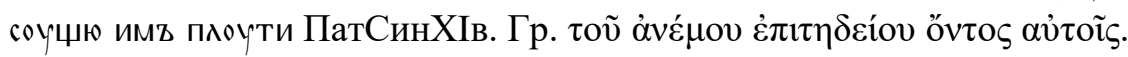

От казаното се вижда, че разглежданата група предложни наречни изрази следват узуса на превеждащия език и не зависят формално от езика на подложката.

Част от основния речников фонд на съвременния български книжовен език продължават да бъдат думи и изрази като посред, после, по мяра, по подобие, поред, по случай, по плът, по сърие, по едно, по малко, по много ${ }^{12}$. Други днес съществуват в съчетание с различен предлог или без предлог: по истинь $-н a-$ истина, по врьмени-навреме, по тънъкоу - изтънко: по вьсьчьскы- всячески, посльд,

11 Форми като тази съществуват като наречия и без предлога по, така че могат да се причислят към наречията с мотивираща дума друго наречие, образувани с междинна адвербиализация.

12 Разбира се, континуантите логично търпят съответните системни фонетични и морфологични промени, настъпили в историята на езика. 
от прилагателни имена - по раноу : рано, по тихоу - тихо. Стилистично маркирани са: като диалектизми - пощо 'след като; тъй като, понеже', послед 'след време, подир', посем-сега 'тепьрва'; като остаряла употреба - потом 'после' (често през Възраждането от рус.). Има и лексикални единици, които са на-

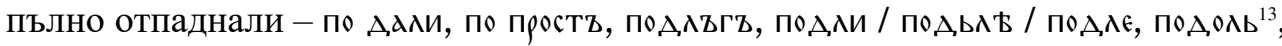

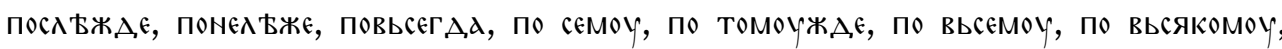
потомоу и др.

\section{Библиография}

БОРКОВСКИЙ-КУЗНЕЦОВ 1963: Борковский, В.И., Кузнецов, П.С. Историческая грамматика русского языка. Москва: АН СССР.

БУСЛАЕВ 1959: Буслаев, Ф. И. Историческая грамматика. Москва: Учпедгиз.

ВАЙАН 1946: Вайан, А. Руководство по старославянскому языку. Москва: Издательство иностранной литературы.

ВЕлЧЕВА 1964: Велчева, Б. Показателни местоимения и наречия в новобългарските паметници от XVII-XVIII в. Известия на Института за български език, кн. 10, 159-235.

ГЕОРГИЕВ 1976: Георгиев, Ст. Система на наречието в съвременния български книжовен език. Дис. за получаване на научната степ. „Доктор на филологическите науки". София.

ДоБРев 1982: Добрев, И. Старобългарска граматика. Теория на основите. София: Наука и изкуство.

ЕФимовА 1989а: Ефимова, В.С. О значений наречий вельми, мъного и зњло в языке старославянских рукописей. Этимология, 1986-1987. Москва.

ЕФимОВА 1989б: Ефимова, В.С. Наречия в языке старославянских рукописей. Диссертация на соискание ученой степени канд. филол. наук. Москва.

ЕФимовА 1989в: Ефимова, В.С. О старославянских наречиях, мотивированных существительными. Советское славяноведение, № 2, 74-84.

ЕФимОвА 1991а: Ефимова, В.С. Старославянские отъадъективные наречия с суфиксом -ъ. Советское славяноведение, № 3, 71-80.

ЕФимовА 1991б: Ефимова, В.С. Об употреблении непроизводных наречий в языке старославянских рукописей. Palaeobulgarica. XV, № 2, 32-36.

ЕФимовА 2006: Ефимова, В. С. Словообразовательная морфемика старославянского наречия. В: Старославянская словообразовательная морфемика. Москва: Институт славяноведения РАН, 298-337.

ИлиЕВА 2017: Илиева, Т. Адвербиализация и препозиционализация на предложни съчетания в старобългарски език. Наречни и полунаречни изрази с предлог въ- Българска реч XXIII/2017, кн.3, 84-107.

ИлиЕВА 2018: Илиева, Т. Адвербиализация и препозиционализация на предложни съчетания в старобългарски език. Наречни и полунаречни изрази с предлог до - Българска реч XXIV/2018, кн. 2, 141-155.

13 Срв. в БЕР I, 409 диалектизмите подолие и подоличе 'плодове по най-долните клони на дърво (Банско)'. 
Илчев 1993а: Илчев, П. Наречия. В: Граматика на старобългарския език. Фонетика, морфология, синтаксис. Гл. ред. Ив. Дуриданов. София: БАН, 314-324.

Илчев 1993б: Илчев, П. Предлози. В: Граматика на старобългарския език Фонетика, морфология, синтаксис. Гл. ред. Ив. Дуриданов. София: БАН, 350-356.

КУзНЕЦОВ 1956: Кузнецов, П.С. Историческая грамматика русского языка /морфология/. Москва: КомКнига.

Миклошич 1899: Миклошич, Фр. Сравнительная морфология славянских языков. Вып. 2, Москва: Университетская типография.

Милетич 1946: Милетич, Л. Старобългарска граматика /синтаксис/. София: Целгра.

Мирчев 1963: Мирчев, К. Историческа граматика на българския книжовен език. София: Народна просвета.

СЛАВОВА 2017: Славова, Т. Старобългарски език. Университетски учебник. София: УИ „Св. Кл. Охридски“.

ФACMEP I-IV/ Fasmer I-IV: Фасмер, М. Этимологический словарь русского языка. Т. IIV. Москва: Наука, 1986-1987.

ХАРАЛАМПИЕВ 1980: Харалампиев, Ив. Качествените наречия на -о и -њ в произведенията на Евтимий Търновски. Трудове на ВТУ „Кирил и Методий“. Т. 15, кн. 2. София, 111-135.

ЧурмAЕВА 1980: Чурмаева, Н.В. Описание наречий в историческом словаре. В: Древнерусский язык. Лексикология и лексикография. Москва: Наука, 60-78.

Ян 1967: Ян, Я. Старославянское наречие как член предложения. Slavia, XXXVI, № 1, 1-23.

ШАнский 1968: Шанский, Н.М. Очерки по русскому словообразованию. Москва: Учпедгиз.

AITZETMÜLLER 1978: Aitzetmüller, R. Altbulgarische Grammatik als Einführung in die slavische Sprachwissenschaft. Freiburgim Breisgau: U.W.Weiher.

DORITSH 1910: Doritsh, Al.. Gebrauch der altbulgarischen Adverbia. Leipzig.

LESKIEN 1919: Leskien, A. Grammatik der altbulgarischen (altkirchenslavischen) Sprache. Heidelberg.

LUNT 1955: Lunt, H. G. Old Church Slavonic Grammar. S' - Gravenhage.

MOSZYŃSKI 1976: Moszyński, L. Starosłowianskie *perdъ - *perdь. Zeszyty naukowewy działu humanistycznego. Filologia polska. Prace językoznawcze Un-tu Gdańskiego, № 4, 123-128.

\section{Източници}

БЕР: Български етимологичен речник. Т. I-VII. София: Проф. М. Дринов, 1971 -.

PБЕ: Речник на българския език. Т. I -XV. София: БАН, 1977 -.

РКБЕНО: Речник на книжовния български език на народна основа (върху текст на Тихонравовия дамаскин). Гл. ред. Е. И. Дьомина. София: В. Траянов, 2012.

СДРЯ: Словарь древнерусского языка XI-XIV вв. В 10 т. Москва: РАН. Ин-т рус. яз., $1988 \rightarrow$

МДРЯ: МДРЯевский, И. И. Материалы для словаря древнерусского языка по письменым памятникам. Т. I-III, Санкт Петербург: Отд-ние рус. яз. и словесн. Имп. АН, 1893-1903. Репринт. Москва: Книга, 1989.

СтбР: Старобългарски речник. Т. І. София, 1999 и Т. ІІ София, 2009. Отг. ред. Д. Иванова-Мирчева.

CC: Старославянский словарь (по рукописям Х-ХІв.). Под редакцией Р. М. Цейтлин, Р. Вечерки и Э. Благовой, Москва: Русский язык, 1999. 
ЦслР: Бончев, Ат. Речник на църковнославянския език. Т. І, София: НБКМ, 2002; Т.ІІ, София: НБКМ, 2012.

LLPsl: Miklosich, F. Lexicon palaeoslovenico-graeco-latinum. Wien 1862-1865.

SJS: Slovnik jazyka staroslovĕnskeho. Ň. I - III. Praha: AV ČR, 1958-1994.

\section{Съкращения на средновековни паметници}

ГБХІв.: Тринадесет слова на Григорий Назиански по ркп. от ХІв. (МДРЯ) ГрНис /МЧФевр/: Григорий Нисийски /Миней-чети за м. февруари/ (МДРЯ) ГригПапа: Беседи върху евангелието на папа Григорий (МДРЯ)

Дан. иг.: Странник игумена Даниила (МДРЯ)

Диоптра: Диоптра Филипова, ркп. ХУв. (МДРЯ)

Ен: Енински апостол (СтбР, СС)

ЕфрСирXIII в.: Паренесис на Ефрем Сирин по ркп. от ХІІІв. (МДРЯ)

ЖитАндрЮр: Житие на Андрей Юродиви (МДРЯ)

ЖитЕвтих /МЧАпр/: Житие на мчк. Евтихий /Миней-чети за м. април/ (МДРЯ)

ЖитПорф /МЧФевр/: Житие на мчк. Порфирий /Миней-чети за м. февруари/ (МДРЯ)

ЖитСтефПерм: Житие на Стефан Пермски (МДРЯ)

ЖитТеодСтуд: Житие на Теодор Студит (МДРЯ)

Изб1073г.: Симеонов Изборник от 1073 г. (МДРЯ)

ИполАнтихр: Слово за Антихриста на Иполит Римски (МДРЯ)

ЙоЕГрам: Йоан Екзарх Граматика (МДРЯ)

КирЙерусХІв.: Катехези на Кирил Йерусалимски по ркп. от XI в. (МДРЯ)

КирТур: Слова на Кирил Туровски (МДРЯ, LLPsl)

КозмаИнд: Топография на Козма Индикоплов (МДРЯ)

КПреслУЕ: Учително евангелие на Константин Преславски (МДРЯ)

Крм: Кормчая книга
ЕфрКрм: Ефремовска Кормчая (МДРЯ)

РязКрм: Рязанска кормчая (МДРЯ)

КПреслПрАр: Слова против арианите в превод на Константин Преславски (МДРЯ)

Мар: Мариинско евангелие (СтбР, СС) Мин1096г.: Служ. миней за м. октомври по ркп. от 1096 г.(МДРЯ)

НестЖитТеод: Житие на преп. Теодосий от монах Нестор(МДРЯ)

Ном: Номоканон, ркп. XVI в. (МДРЯ)

Остр: Остромирово евангелие (МДРЯ)

ПАХІв.: Пандект на Антиох по ркп. от ХІв. (МДРЯ)

Парим: Паримейник (МДРЯ)

ПатСинХІв.: Синайски патерик по ркп. от ХІв.(МДРЯ)

ПВЛ: Повест за отминалите години (МДРЯ)

ПНЧ: Пандети на Никон Черногорец (МДРЯ) Прол: Пролог, ркп. ХVІв. (МДРЯ, LLPsl)

Псков1Л: Първи Псковски летопис (МДРЯ)

СбХVІв.: Сборник по ркп. от XVIв. (МДРЯ)

Син: Синайски псалтир (СтбР, СС)

СинЕвх: Синайски евхологий (СтбР, CC)

Служ: Служебник

СинСлуж: Синайски служебник (СтбР, СС)

Служ. ект. суг.: Служебник - сугуба ектения (ЦслР)

СказБорГл: Сказание за Борис и Глеб (МДРЯ)

СуздЛ: Суздалски летопис (МДРЯ)

Супр: Супрасълски сборник (СтбР, СС) 
Тп: Типик (ЦслР)

ТрПр: Троянска притча (LLPsl)

Упир: Ръкопис на Упир Лихий от 1047 г. (МДРЯ)

Уст пр. 1193г.: Църковен устав преди 1193 г.

Хрон: Хроника. Полное собрание русских летописей. Санктпетербург. 1846.

ХронГАм: Хроника на Георги Амартол (МДРЯ)

ХроногрХVІв.: Хронограф ХVІв. (МДРЯ)

crys.-duš. (LLPsl): Chrysovula cara Stephana Dušana

men.-leop. (LLPsl): Миней по ркп.

XVI в. men.-mih. (LLPsl): Menaeum cod. XVIв.

(Mihanović)

men.-vuk. (LLPsl):

mir. (LLPsl): Miracula beatae virginis Mariae, ркп. XVII.

mon.-serb. (LLPsl): Monumenta serbica spectantia historiam Serbiae, Bosnae, Ragusii. Ed. Fr. Miklosich. Vindobonae, 1858

pent.-mih. (LLPsl): Pentateuchus et aliae quaedam veteris testamentis partesno ркп. XVI в.

Šiš (LLPsl): Шишатовацки апостол

\section{Съкращения на библейски книги Лексикографски съкращения}

Бт - Книга Битие
Изх - Книга Изход
Втз - Второзаконие
ИсНав - Книга Иисус Навин
Пс - Книга Псалтир
Ис - Книга на прор. Исая
Мих - Книга на прор. Михей
Мт - Евангелие според Матей
Йо - Евангелие според Йоан

Татяна ИЛИЕВА

Cyril and Methodius Research Centre ilieva_tatyana@abv.bg

Sofia, Bulgaria 